\title{
POTENSI ANTIOKSIDAN EKSTRAK ETANOL DAUN BELIMBING WULUH (Averrhoa bilimbi L.) DAN PENGARUHNYA TERHADAP KADAR GULA DARAH PADA TIKUS WISTAR JANTAN YANG DIINDUKSI STREPTOZOTOCIN (STZ)
}

\author{
Tri Wahyuni ${ }^{1}$, Eva Nurinda ${ }^{2 *}$, Rizal Fauzi ${ }^{3}$
}

\begin{abstract}
${ }^{1}$ Program Studi Sarjana Farmasi; Fakultas IImu-IImu Kesehatan;Universitas Alma Ata ${ }^{2}$ Program Studi Sarjana Farmasi; Fakultas IImu-IImu Kesehatan;Universitas Alma Ata

${ }^{3}$ Program Studi Sarjana Farmasi; Fakultas IImu-Ilmu Kesehatan;Universitas Alma Ata Email: wahyunitri296@yahoo.com; evanurinda@almaata.ac.id; rizalfauzi@almaata.ac.id

\section{Korespondensi:}

Eva Nurinda

Program Studi Sarjana Farmasi, Fakultas IImu-Ilmu Kesehatan, Universitas Alma Ata evanurinda@almaata.ac.id
\end{abstract}

\begin{abstract}
Abstrak
Diabetes melitus merupakan salah satu penyakit metabolisme yang ditandai dengan kondisi hiperglikemia yang diakibatkan oleh kurangnya insulin atau terjadinya resistensi insulin. Belimbing wuluh merupakan salah satu tanaman herbal yang mengandung antioksidan sehingga perlu dilakukan uji potensi antioksidan ekstrak etanol daun belimbing wuluh terhadap kadar gula darah. Metode yang digunakan yaitu penelitian eksperimental dengan rancangan pretest and post-test with control group design dengan 24 sampel tikus wistar jantan yang terbagi dalam 4 kelompok yaitu 2 kelompok kontrol (kelompok normal dan kelompok hiperglikemik) 1 kelompok pembanding (glibenklamid) dan 1 kelompok perlakuan (ekstrak etanol daun belimbing wuluh). Ekstrak etanol daun belimbing wuluh (Averrhoa bilimbi L.) dan glibenklamid mempunyai efek dalam menurunkan kadar gula darah pada tikus yang diinduksi streptozotosin yang dibuktikan dengan adanya perubahan rata-rata besar kadar gula darah tikus pretest perlakuan glibenklamid sebesar 258,4117 $\mathrm{mg} / \mathrm{dL}$ dan setelah perlakuan sebesar $126,4300 \mathrm{mg} / \mathrm{dL}$ dan perubahan rata-rata kadar gula darah pada pre ekstrak etanol daun belimbing wuluh sebesar $257,7717 \mathrm{mg} / \mathrm{dL}$ dan setelah perlakuan sebesar 149,0933 mg/dL. Kapasitas antioksidan darah pada kelompok yang diberi glibenklamid dan kelompok yang diberi ekstrak etanol daun belimbing wuluh menunjukkan nilai signifikansi 1,000 yang berarti tidak ada perbedaan bermakna antara kelompok pembanding (glibenklamid) dengan kelompok perlakuan (ekstrak etanol daun belimbing wuluh). Kapasitas antioksidan darah pada kelompok yang diberi glibenklamid dan kelompok yang diberi ekstrak etanol daun belimbing wuluh tidak berbeda signifikan jika dilihat secara statistik yang dapat dilihat dari angka signifikansinya yaitu 0,880 . Hal ini menunjukkan bahwa kandungan antioksidan ekstrak etanol daun belimbing wuluh berpengaruh terhadap penurunan kadar gula pada kondisi hiperglikemia.
\end{abstract}

Kata Kunci: antioksidan; Averrhoa bilimbi L.; diabetes melitus; FRAP; kadar gula darah 


\title{
ANTIOXIDANT POTENTIAL FOR LEAF EXTRACT OF BELIMBING WULUH (Averrhoa bilimbi L.) AND ITS EFFECT ON BLOOD GLUCOSE LEVELS IN STREPTOZOTOSIN-INDUCED WISTAR RATS
}

\begin{abstract}
Diabetes mellitus is one of the metabolic diseases characterized by hyperglycemia caused by lack of insulin or the occurrence of insulin repression. Averrhoa bilimbi L. is one of the herbal plants containing antioxidants so it is necessary to test the potential of ethanol extract of Averrhoa bilimbi L. leaves against blood sugar levels. The method used was experimental research with pretest and post-test with control group design with 24 samples of male Wistar mice divided into 4 groups namely 2 control groups (normal group and hyperglycemic group) 1 comparison group (glibenclamide) and 1 treatment group (ethanol extract of Averrhoa bilimbi L. leaves). Ethanol extract of Averrhoa bilimbi L. leaves (Averrhoa bilimbi L.) and glibenclamide had an effect in lowering blood sugar levels in mice induced streptozotocin as evidenced by the change in the average blood sugar levels of mice pre glibenclamide treatment of $258.4117 \mathrm{mg} / \mathrm{dL}$ and after treatment of $126.4300 \mathrm{mg} / \mathrm{dL}$ and changes in average blood sugar levels in pre-extract ethanol Averrhoa bilimbi L. leaves of $257.7717 \mathrm{mg} / \mathrm{dL}$ and after treatment of $149.0933 \mathrm{mg} / \mathrm{dL}$. The antioxidant capacity of the blood in the group given glibenclamide and the group given ethanol extract of Averrhoa bilimbi L. leaves showed a significance value of 1,000 which means there is no meaningful difference between the comparative group (glibenclamide) with the treatment group (ethanol extract of Averrhoa bilimbi L. leaves). The antioxidant capacity of the blood in the group given glibenclamide and the group given ethanol extract of Averrhoa bilimbi L. leaves does not differ significantly when viewed statistically which can be seen from the significance figure of 0.880. This indicates that the antioxidant content of the ethanol extract of Averrhoa bilimbi L. leaves has an effect on reducing sugar levels in hyperglycemic conditions.
\end{abstract}

Keywords: antioxidants; Averrhoa bilimbi L. leaves; blood glucose level; diabetes mellitus; FRAP

\section{PENDAHULUAN}

Indonesia kaya akan bahan herbal yang berasal dari alam yang sering dimanfaatkan sebagai pengobatan berbagai penyakit ${ }^{1}$. Secara turun temurun masyarakat Indonesia menggunakan tanaman herbal sebagai pengobatan. Salah satu contoh tanaman obat yang sering digunakan sebagai tanaman obat yaitu daun belimbing wuluh (Averrhoa bilimbi L.). Daun belimbing wuluh (Averrhoa bilimbi L.) adalah tanaman yang mudah tumbuh di negara beriklim tropis. Di Indonesia belimbing wuluh sudah mulai dimanfaatkan salah satunya adalah daunnya. Ekstrak etanol daun belimbing wuluh memiliki aktivitas dalam penurunan kadar gula dara ${ }^{2}$. Secara umum tanaman belimbing wuluh mengandung tannin, flavonoid, saponin, minyak atsiri dan fenol. Dalam penelitian sebelumnya disebutkan bahwa kandungan dalam daun belimbing wuluh mampu berperan sebagai penurun kadar gula darah yaitu flavonoid, saponin, dan tanin ${ }^{3}$. 
Pada dasarnya penyakit dibagi menjadi dua jenis, yaitu penyakit menular dan penyakit tidak menular atau yang biasa disebut dengan penyakit degeneratif. Salah satu contoh penyakit degeneratif yaitu diabetes melitus ${ }^{4}$. Diabetes melitus kini sudah menjadi masalah besar kesehatan di dunia. Prevalensi diabetes melitus saat ini terus bertambah terutama di negara yang berada dalam lingkup industrialisasi dan negara berkembang. Prevalensi diabetes di dunia (dengan usia yang distandarisasi) mengalami peningkatan sekitar dua kali lipat dari tahun 1980. Selama beberapa tahun terakhir, angka kejadian diabetes mengalami peningkatan lebih tinggi di negara berpenghasilan menengah dan rendah dibandingkan pada negara berpenghasilan tinggi ${ }^{5}$.

Prevalensi diabetes melitus menurut diagnosis dokter pada penduduk yang berumur $\geq 15$ tahun menurut Provinsi, di D.I Yogyakarta pada tahun 2013 sebanyak 2,6\% dan pada tahun 2018 sebanyak 3,1\%. Jika dibandingkan pada tahun 2013, angka kejadian diabetes melitus menurut diagnosis dokter pada penduduk berumur $\geq 15$ tahun meningkat menjadi $2 \%$. Sedangkan prevalensi diabetes melitus menurut diagnosis dokter pada penduduk semua umur dan prevalensi rutin periksa kadar gula darah (KGD) menurut provinsi, di D.I Yogyakarta pada tahun 2013 sebanyak 3,7\% dan pada tahun 2018 sebanyak 2,4\% ${ }^{5}$. Pengobatan diabetes melitus saat ini banyak menggunakan obat-obatan sintetik. Seperti yang kita ketahui bahwa obat-obatan sintetik memiliki banyak sekali efek samping, contohnya seperti glibenklamid yang biasa digunakan sebagai pengobatan lini pertama pada diabetes melitus tipe 2 apabila dengan modifikasi gaya hidup tidak dapat mengontrol kadar glukosa darah. Efek samping yang sering timbul yaitu hipoglikemia, konstipasi, tremor, mual, dan pusing ${ }^{6}$.

Pada penelitian sebelumnya disebutkan juga bahwa diabetes melitus merupakan penyakit degeneratif sehingga obat-obatan yang diberikan harus dikonsumsi secara teratur dan terus menerus bahkan bisa sampai seumur hidup, karena penyakit degeneratif yang secara langsung dapat berpengaruh terhadap penurunan kondisi ginjal pada pasien nefropati diabetic ${ }^{7}$. Kadar gula yang berlebih diperkirakan dapat diturunkan menggunakan senyawa yang mengandung flavonoid, diduga bahwa kandungan flavonoid dapat berperan penting sebagai antioksidan dan antidiabetes ${ }^{8,9}$. Salah satu flavonoid banyak terkandung dalam budah daun belimbing wuluh (Averrhoa bilimbi L.) yaitu flavonoid golongan flavon/ flavonon dan dihidroflavonol ${ }^{10,11}$. Menilik hasil penelitian terdahulu bahwa daun belimbing wuluh berpotensi mengandung antioksidan tinggi sehingga akan berperan penting dalam kendali glikemik, maka penelitian ini akan mengetahui bagaimana potensi antioksidan daun belimbing wuluh (Averrhoa bilimbi L.) terhadap kadar gula darah tikus wistar yang telah 
diinduksi streptozotosin.

\section{METODE PENELITIAN}

\section{Alat dan Bahan}

Bahan sampel yang digunakan pada penelitian ini adalah ekstrak etanol daun belimbing wuluh (Averrhoa bilimbi L.). Bahan kimia yang digunakan adalah streptozotocin, glibenklamid, nicotinamid, $\mathrm{NaCl} 0,9 \%$, Buffer sitrat 0,1 M (pH 4,5), CMC Na 0,5\%, aquadest dan etanol $70 \%$.

\section{Rancangan Penelitian}

Metode yang digunakan dalam penelitian ini yaitu penelitian eksperimental dengan rancangan pretest and post-test with control group design dengan 24 sampel tikus wistar jantan yang terbagi dalam 4 kelompok yaitu 2 kelompok kontrol (kelompok normal dan kelompok hiperglikemik) 1 kelompok pembanding (glibenklamid) dan 1 kelompok perlakuan (ekstrak etanol daun belimbing wuluh).

\section{Etik Penelitian}

Penelitian ini telah mendapatkan izin dan etik penelitian melalui Komisi Etik Penelitian Kesehatan (KEPK) Universitas Alma Ata dengan Nomor: KE/AA/III/1014/EC/2020.

\section{HASIL DAN PEMBAHASAN}

\section{Hasil Determinasi dan Kandungan Senyawa Metabolit Sekunder Daun Belimbing Wuluh}

Sebelum melakukan penelitian, maka dilakukan determinasi pada tanaman belimbing wuluh yang akan dibuat ekstrak. Bagian tanaman yang dideterminasi yaitu bagian daunnya karena pada penelitian ini yang digunakan adalah daun belimbing wuluh. Determinasi dilakukan di laboratorium Biologi Universitas Ahmad Dahlan Yogyakarta. Tujuan dilakukan determinasi yaitu untuk membuktikan kebenaran bahan bahan yang digunakan pada penelitian. Hasil determinasi tanaman yang telah dilakukan, dapat disimpulkan bahwa daun belimbing wuluh adalah Averrhoa bilimbi L. dengan data 1b-2b-3b-4b-12b-13b-14b17b-18b-19b-20b-21b-22b-23b-24b-25b-26b-27a-28b-29b-30b-31a-32a-33a-34a-35a-36d37b-38b-39b-41b-42b 0-44b-45b-46e-50b-51b-53b-54b-56b-57b-58b-59d-72b-73b-74a75b-76a-77b-103c-104b-106b-107a-108b-109b-110a-111b-112a-113a.

Setelah dilakukan determinasi tanaman kemudian sampel yang digunakan dalam penelitian ini berupa ekstrak daun belimbing wuluh yang di dapatkan dari wilayah Yogyakarta 
dilakukan uji fitokimia yang berpotensi sebagai kontrol glikemik dengan kandungan antioksidan tinggi (Tabel 1).

Tabel I. Hasil analisis skrining fitokimia secara kualitatif

\begin{tabular}{cc}
\hline Senyawa & Hasil \\
\hline Flavonoid & + \\
Saponin & + \\
Tanin & + \\
Alkaloid & + \\
Steroid & + \\
Glikosida & + \\
\hline
\end{tabular}

Keterangan: $(+)=$ mengandung senyawa metabolit sekunder;

$(-)=$ tidak mengandung senyawa metabolit sekunder

Uji fitokimia dilakukan dengan tujuan untuk mengetahui kandungan apa saja yang terdapat dalam ekstrak etanol daun belimbing wuluh. Pada penelitian ini pada saat uji fitokimia daun belimbing wuluh mengandung flavonoid dengan tahapan uji fitokimia yaitu dengan cara sebanyak $5 \mathrm{ml}$ ekstrak yang dilarutkan dalam etanol kemudian ditambahkan serbuk Mg dan ditetesi HCL pekat 5 tetes. Bila hasilnya berwarna merah atau kuning atau jingga berarti positif mengandung flavonoid.

Ekstrak etanol daun belimbing wuluh juga mengandung saponin dengan tahapan uji yaitu Ekstrak etanol daun belimbing wuluh ditambahkan $10 \mathrm{ml}$ aquades panas dan dilarutkan terlebih dahulu sambal dipanaskan dalam penangas air kemudian di kocok kuat-kuat. Bila tidak terbentuk buih berarti negatif, namun bila tetap berbuih setelah didiamkan selama 10 menit kemudian ditambahkan HCL $2 \mathrm{~N}$ diperoleh buih tersebut tidak hilang, maka positif mengandung saponin. Ekstrak etanol daun belimbing wuluh juga mengandung tannin dengan tahapan uji yaitu Sebanyak $5 \mathrm{ml}$ ekstrak dilarutkan dalam etanol ditambahkan dengan pereaksi $\mathrm{FeCl}_{3}$. Ekstrak yang mengandung tannin akan berwarna biru atau hijau kehitaman. Ekstrak etanol daun belimbing wuluh juga mengandung alkaloid dengan tahapan uji yaitu Ekstrak dilarutkan dalam pelarut etanol kemudian hasil yang diperoleh disaring untuk mendapatkan filtratnya. Fltrat dibagi menjadi 3 bagian masing-masing $5 \mathrm{ml}$. Lalu filtrat 1 ditambahkan pereaksi Mayer terbentuk endapan menggumpal putih atau kuning yang larut dalam methanol, filtrat 2 ditambahkan pereaksi Dragendorf terbentuk endapan coklat jingga, filtrat 3 Bourchard terbentuk endapan coklat hitam ${ }^{12}$. Jika dua atau tiga bagian terdapat endapan yang brarti positif alkaloid. Dari pembahasan tersebut berarti sesuai 
Tri Wahyuni, Eva Nurinda, Rizal Fauzi

Potensi Antioksidan Ekstrak Etanol Daun Belimbing Wuluh (Averrhoa Bilimbi L.) dan Pengaruhnya Terhadap Kadar Gula Darah Pada Tikus Wistar Jantan yang Diinduksi Streptozotocin (STZ)

dengan penelitian sebelumnya. Menurut penelitian sebelumnya, daun belimbing wuluh mengandung flavonoid, saponin, tannin, alkaloid ${ }^{9}$.

Adanya potensi kandungan senyawa metabolit sekunder dalam ekstrak etanol daun belimbing wuluh yang diperoleh dari hasil ekstraksi dari daun belimbing wuluh dengan penyari etanol 70\% dilanjutkan dalam uji farmakologi untuk mengetahui aktivitasnya. Dalam pembuatan ekstrak ini perbandingan antara simplisia dan pelarut yang digunakan yaitu 1:10 yaitu simplisia sebanyak 100 gram dan etanol $70 \% 1000 \mathrm{ml}$. Ekstraksi dilakukan dengan cara maserasi dan remaserasi selama 2 hari dengan sesekali diaduk dan ditutup rapat. Dan rendemen yang dihasilkan adalah $20,5 \%$. Tujuan dilakukan perhitungan yaitu untuk mengetahui berapa hasil ekstrak yang didapatkan. Nilai rendemen juga berkaitan dengan banyaknya kandungan bioaktif yang terkandung. Senyawa bioaktif merupakan senyawa yang terkandung dalam tubuh hewan maupun tumbuhan. Senyawa ini memiliki berbagai manfaat bagi kehidupan manusia, diantaranya dapat dijadikan sebagai sumber antioksidan ${ }^{13}$.

\section{Potensi Daun Belimbing Wuluh sebagai Kontrol Glikemik}

Kondisi hiperglimia merupakan salah satu penanda diabetes melitus, kadar glukosa darah tikus dalam kategori normal yaitu $50-135 \mathrm{mg} / \mathrm{dl}^{14}$. Penelitian ini merupakan penelitian eksperimental laboratorik dengan pendekatan pretest dan post-test control group design yang mempunyai tujuan untuk mengetahui pengaruh pemberian ekstrak etanol daun belimbing wuluh (Averrhoa bilimbi L.) terhadap kadar gula darah dan pada tikus jantan galur Wistar yang diinduksi STZ. Perlakuan dilakukan selama 10 hari, dimana tikus sudah diadaptasikan selama 3 hari sebelumnya dan dilakukan pengukuran kadar gula darah untuk memastikan jika tikus belum mengalami diabetes. Pada hari keempat tikus diberi perlakuan sesuai dengan kelompok yang sudah ditentukan yaitu pada kelompok 2,3 dan 4 diberi induksi streptozotosin kemudian dilakukan pengukuran kadar gula darah dengan tujuan memastikan jika kelompok 2, 3 dan 4 sudah mengalami kenaikan kadar gula darah atau mengalami diabetes.

Pada hari keempat tikus mulai diberikan perlakuan selama 10 hari dan dilakukan pengukuran kadar gula darahpada hari ke-10 untuk mengetahui apakah ada pengaruh pemberian perlakuan. Pengambilan darah juga dilakukan untuk mengetahui berapa besar kadar antioksidan dalam darah tikus dengan menggunakan metode Ferric Reducing Ability of Plasma (FRAP). Pada Tabel 2 menunjukkan kondisi hiperglikimia pada tikus yang terinduksi STZ sebagai permodelan diabetes melitus tipe 2 dan rerata penurunannya setelah 
mendapatkan ekstrak daun belimbing wuluh.

Sebelum dilakukan uji one-way ANOVA, data penelitian harus diketahui apakah data terdistribusi normal. Uji normalitas data dilakukan dengan Saphiro Wilk test. Kriteria ujinya yaitu bila nilai signifikansi lebih besar dari 0,05 maka data terdistribusi secara normal. Sebaliknya, bila nilai signifikansi lebih kecil dari 0,05 maka data tidak terdistribusi secara normal. Jika data tidak terdistribusi normal maka uji dapat menggunakan analisis non parametrik. Berdasarkan uji normalitas menggunakan Shapiro-Wilk didapatkan hasil analisis pretest dan post-test kadar gula darah pada keempat kelompok didapatkan nilai signifikansi lebih besar dari 0,05 yaitu nilai pretest kadar gula darah 0,$865 ; 0,437 ; 0,200 ; 0,555$ dan nilai signifikansi pada kadar gula darah post-test yaitu 0,$909 ; 0,224 ; 0,587 ; 0,680$. Nilai signifikansi tersebut lebih besar dari 0,05 yang dapat disimpulkan bahwa kadar gula darah terdistribusi normal.

Kemudian dilakukan uji one-way ANOVA untuk mengetahui apakah hipotesis alternatif yang diajukan peneliti dapat diterima atau tidak. Uji one way ANOVA dapat diterima jika nilai signifikansi kurang dari 0,05 yang berarti terdapat perbedaan yang nyata. Pada pre tes kadar gula darah didapatkan nilai sig 0,000 dan post tes kadar gula darah didapatkan nilai signifikansi yaitu $p<0,001$ sehingga dapat dikatakan bahwa pada kondisi pre-perlakuan, terdapat 2 atau lebih kelompok yang memiliki perbedaan rata-rata yang signifikan, begitu pula pada kondisi post perlakuan (Tabel 2).

Tabel II. Hasil pengukuran kadar gula darah pada tikus jantan galur Wistar yang terinduksi STZ

\begin{tabular}{|c|c|c|c|c|c|c|}
\hline \multirow[b]{2}{*}{ Kelompok } & \multicolumn{2}{|c|}{ Pretest $(\mathrm{mg} / \mathrm{dL})$} & \multicolumn{4}{|c|}{ Post-test (mg/dL) } \\
\hline & $\begin{array}{c}\text { Rerata } \\
\text { Kadar gula } \\
\text { darah (mg/ } \\
\text { dL) }\end{array}$ & $\begin{array}{c}\text { Rerata Kadar } \\
\text { gula darah } \\
\text { setelah } \\
\text { induksi STZ } \\
\text { (mg/dL) }\end{array}$ & $p$-value & $\begin{array}{l}\text { Rerata Kadar } \\
\text { gula darah } \\
\text { (mg/dL) }\end{array}$ & $p$-value & $\begin{array}{c}\text { Rerata } \\
\text { Penurunan } \\
\text { kadar gula } \\
\text { darah } \\
\text { (mg/dL) }\end{array}$ \\
\hline $\begin{array}{c}\text { K1 } \\
\text { (kelompok } \\
\text { kontrol normal) }\end{array}$ & 71.7367 & 73,1733 & & 76,0800 & & $-2,91$ \\
\hline $\begin{array}{c}\text { K2 } \\
\text { (kelompok } \\
\text { hiperglikemik) }\end{array}$ & 68.9733 & 257,3683 & & 261,9250 & & $-4,55$ \\
\hline $\begin{array}{c}\text { K3 } \\
\text { (kelompok } \\
\text { pembanding) }\end{array}$ & 69.2367 & 258,4117 & $p<0,001$ & 126,4300 & $p<0,001$ & 131,98 \\
\hline $\begin{array}{c}\text { K4 } \\
\text { (kelompok } \\
\text { perlakuan) }\end{array}$ & 68.1183 & 257,7717 & & 149,0933 & & 108,68 \\
\hline
\end{tabular}


Potensi Antioksidan Ekstrak Etanol Daun Belimbing Wuluh (Averrhoa Bilimbi L.) dan Pengaruhnya Terhadap Kadar Gula Darah Pada Tikus Wistar Jantan yang Diinduksi Streptozotocin (STZ)

Pada Tabel 2 menunjukkan bahwa pada hari ke-0 kadar gula darah tikus pada keadaan normal. Pada hari ke-1 (pretest) intervensi pada kelompok 2,3 dan 4 mengalami kenaikan kadar gula darah yang disebabkan oleh pemberian streptozotosin dan pada hari ke-10 (post-test) pada kelompok 3 dan 4 mengalami penurunan kadar gula darah yang disebabkan oleh pemberian glibenklamid dan ekstrak etanol daun belimbing wuluh. Jika dilihat dari rata-rata kadar gula darah pada post-test (Tabel 3). Glibenklamid mempunyai kemampuan menurunkan kadar gula darah yang lebih tinggi dibandingkan dengan ekstrak etanol daun belimbing wuluh. Pada nilai signifikansi pada uji one-way ANOVA pretest menunjukkan $p<0,001$ yang berarti menunjukkan ada beda bermakna pada 2 atau lebih kelompok, begitupun dengan post-test perlakuan menunjukkan nilai signifikansi sebesar $p<0,001$ yang artinya menunjukkan adanya perbedaan bermakna pada 2 atau lebih kelompok. Pada Gambar 1 menunjukkan selisih kadar gula darah pada setiap kelompok.

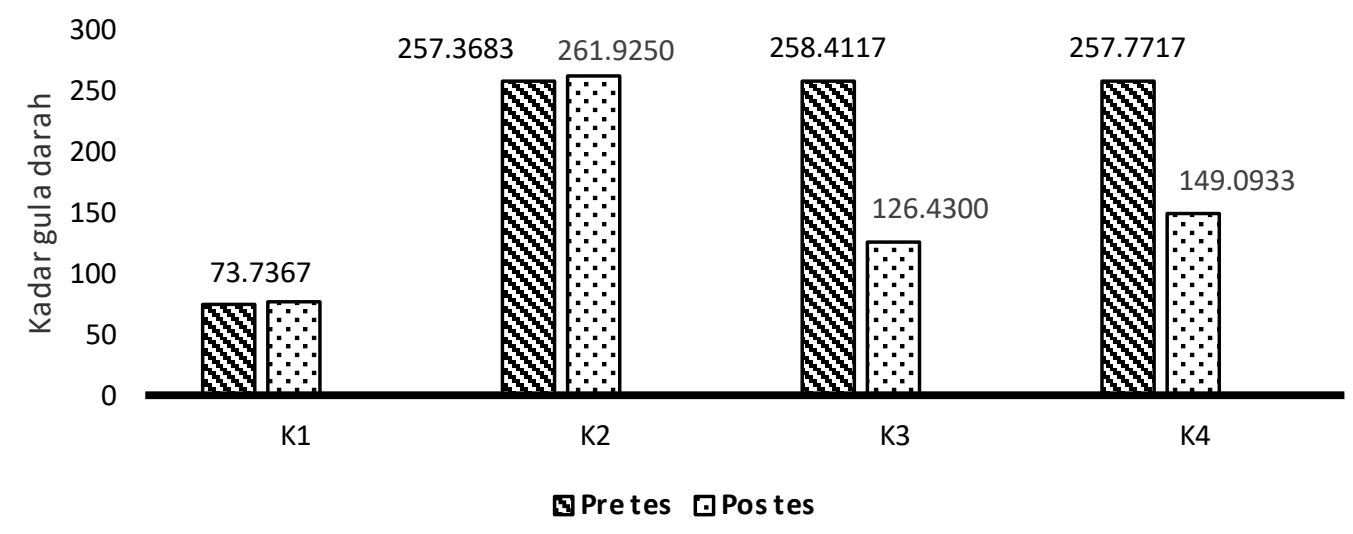

Gambar 1. Rerata selisih kadar glukosa darah pretest dan post-test mendapatkan ekstrak daun belimbing wuluh

Pada hasil pretest dan post-test kadar gula darah kelompok 3 dan 4 dilakukan pengujian karena ingin membandingkan antara kelompok pembanding (glibenklamid) dan perlakuan (ekstrak etanol daun belimbing wuluh). Pada pretest dan post-test kadar gula darah kelompok pembanding dan kelompok perlakuan diperoleh nilai signifikansi 1,000 yang berarti menunjukkan tidak ada perbedaan antara kedua kelompok yang bermakna. Hasil tersebut dapat dikatakan bahwa jika dianalisis secara statistik, rata-rata kadar gula darah tikus sebelum dan sesudah perlakuan pada kelompok yang diberikan glibenklamid tidak berbeda bermakna dengan rata-rata kadar gula darah sebelum dan sesudah perlakuan pada kelompok tikus yang diberi ektrak belimbing wuluh. 
Tabel III. Hasil pos hoc rerata kadar glukosa post-test

\begin{tabular}{|c|c|c|c|}
\hline \multicolumn{2}{|c|}{ Kelompok Penelitian } & p-value & Keterangan \\
\hline \multirow{3}{*}{ K1 } & $\mathrm{K} 2$ & $\mathrm{p}<0,001$ & Berbeda Bermakna \\
\hline & $\mathrm{K} 3$ & $p<0,001$ & Berbeda Bermakna \\
\hline & $\mathrm{K} 4$ & $p<0,001$ & Berbeda Bermakna \\
\hline \multirow{3}{*}{$\mathrm{K} 2$} & $\mathrm{~K} 1$ & $p<0,001$ & Berbeda Bermakna \\
\hline & K3 & 0,004 & Berbeda Bermakna \\
\hline & $\mathrm{K} 4$ & 0,022 & Berbeda Bermakna \\
\hline \multirow{3}{*}{ K3 } & $\mathrm{K} 1$ & $p<0,001$ & Berbeda Bermakna \\
\hline & $\mathrm{K} 2$ & 0,004 & Berbeda Bermakna \\
\hline & $\mathrm{K} 4$ & 1.000 & Tidak Berbeda Bermakna \\
\hline \multirow{3}{*}{ K4 } & $\mathrm{K} 1$ & $\mathrm{p}<0,001$ & Berbeda Bermakna \\
\hline & $\mathrm{K} 2$ & 0.022 & Berbeda Bermakna \\
\hline & K3 & 1.000 & Tidak Berbeda Bermakna \\
\hline
\end{tabular}

Jika dilihat dari data penelitian, rata-rata kadar gula darah post perlakuan kelompok menggunakan glibenklamid adalah $126,4300 \mathrm{mg} / \mathrm{dL}$, sedangkan rata-rata kadar gula darah post perlakuan kelompok yang menggunakan ekstrak adalah 149,0933 mg/dL. Maka dapat dikatakan ekstrak belimbing wuluh dengan dosis $15 \mathrm{mg}$ yang diberikan selama 10 hari dapat menurunkan kadar gula darah namun masih lebih baik glibenklamid dalam mengontrol kadar gula darah karena bisa dilihat dari hasil signifikansi pada uji pos hoc. Menurut penelitian sebelumnya daun belimbing wuluh mengandung flavonoid yang sangat berperan penting sebagai antioksidan dan antidiabetes, dimana flavonoid merupakan senyawa fenol yang memiliki aktivitas farmakologi dengan cara menekan radikal bebas yang terjadi akibat peningkatan kadar glukosa dalam darah pada pasien diabetes melitus ${ }^{15,16}$.

\section{Hasil Pemeriksaan Kapasitas Antioksidan Menggunakan Metode FRAP (Ferric Reducing} Ability of Plasma)

Pada analisis kapasitas antioksidan darah menggunakan metode FRAP (Tabel 4). Kapasitas antioksidan sangat berhubungan dengan diabetes melitus karena antioksidan memiliki mekanisme kerja menekan pembentukan reactive oxigen species (ROS) dengan menghambat enzim dalam pembentukan ROS dan meningkatkan regulasi serta proteksi dari antioksidan ${ }^{17,18}$. Berdasarkan uji normalitas menggunakan Shapiro-Wilk didapatkan hasil analisis pretest dan post-test FRAP darah pada keempat kelompok didapatkan nilai signifikansi lebih besar dari 0,05 yaitu nilai pretest FRAP darah 0,959; 0,917; 0,585; 0,863 dan nilai signifikansi post-test FRAP yaitu 0,$984 ; 0,525 ; 0,307 ; 0,862$. Nilai signifikansi yang lebih 
Tri Wahyuni, Eva Nurinda, Rizal Fauzi

Potensi Antioksidan Ekstrak Etanol Daun Belimbing Wuluh (Averrhoa Bilimbi L.) dan Pengaruhnya Terhadap Kadar Gula Darah Pada Tikus Wistar Jantan yang Diinduksi Streptozotocin (STZ)

besar dari 0,05, maka dapat disimpulkan bahwa kapasitas antioksidan darah terdistribusi normal.

Tabel IV. Hasil FRAP

\begin{tabular}{|c|c|c|c|c|c|}
\hline Kelompok & $\begin{array}{l}\text { Pretest } \\
\text { (mg/dL) }\end{array}$ & $p$-value & $\begin{array}{l}\text { Post-test (mg/ } \\
\mathrm{dL} \text { ) }\end{array}$ & $p$-value & $\begin{array}{c}\text { Peningkatan } \\
\text { FRAP }\end{array}$ \\
\hline $\begin{array}{c}\text { K1 } \\
\text { (kelompok kontrol } \\
\text { normal) }\end{array}$ & $\begin{array}{l}77,8200 \\
\mathrm{nmol} / \mathrm{ml}\end{array}$ & & $\begin{array}{c}73,6850 \mathrm{nmol} / \\
\mathrm{ml}\end{array}$ & & $-4,135$ \\
\hline $\begin{array}{c}\text { K2 } \\
\text { (kelompok } \\
\text { hiperglikemik) }\end{array}$ & $\begin{array}{l}23,5600 \\
\mathrm{nmol} / \mathrm{ml}\end{array}$ & & $\begin{array}{c}14,5367 \mathrm{nmol} / \\
\mathrm{ml}\end{array}$ & & $-9,023$ \\
\hline $\begin{array}{c}\text { K3 } \\
\text { ( kelompok } \\
\text { pembanding) }\end{array}$ & $\begin{array}{l}25,3133 \\
\mathrm{nmol} / \mathrm{ml}\end{array}$ & $p<0,001$ & $\begin{array}{c}60,7767 \mathrm{nmol} / \\
\mathrm{ml}\end{array}$ & $p<0,001$ & 35,464 \\
\hline $\begin{array}{c}\text { K4 } \\
\text { (kelompok perlakuan) }\end{array}$ & $\begin{array}{l}25,6883 \\
\mathrm{nmol} / \mathrm{ml}\end{array}$ & & $\begin{array}{c}52,7583 \mathrm{nmol} / \\
\mathrm{ml}\end{array}$ & & 27,068 \\
\hline
\end{tabular}

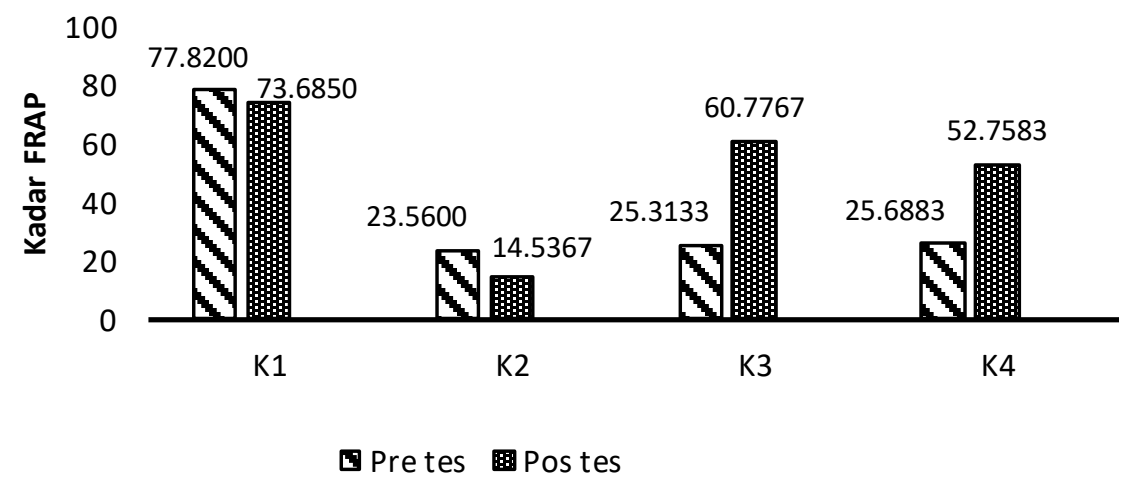

Gambar 2. Pengukuran nilai FRAP

Hasil grafik peningkatan kapasitas antioksidan juga dapat dilihat dari Gambar 2 untuk mengetahui grafik peningkatan kapasitas antioksidan yang dihasilkan pada setiap kelompok penelitian. Selanjutnya dilakukan uji one-way ANOVA, Pada pretest FRAP di dapatkan nilai $p<0,001$ dan post-test FRAP didapatkan nilai $p<0,001$, sehingga dapat disimpulkan bahwa pada kondisi pretest perlakuan, terdapat perbedaan rata-rata yang signifikan antara dua atau lebih kelompok, begitu pula pada kondisi post-test perlakuan (Tabel 5). 
Tabel V. Hasil Pos Hoc Pre-Pos Test FRAP

\begin{tabular}{cccc}
\hline \multirow{2}{*}{ Kelompok Penelitian } & p-value & \multicolumn{1}{l}{ Keterangan } \\
\hline \multirow{2}{*}{ K1 } & K2 & $p<0,001$ & Berbeda Bermakna \\
\cline { 2 - 4 } & K3 & $p<0,001$ & Berbeda Bermakna \\
\cline { 2 - 4 } & K4 & $p<0,001$ & Berbeda Bermakna \\
\cline { 2 - 4 } K2 & K1 & $p<0,001$ & Berbeda Bermakna \\
\cline { 2 - 4 } & K3 & $p<0,001$ & Berbeda Bermakna \\
\hline \multirow{3}{*}{ K3 } & K1 & 0,031 & Berbeda Bermakna \\
\cline { 2 - 4 } & K2 & $p<0,001$ & Berbeda Bermakna \\
\cline { 2 - 4 } & K4 & 0,880 & Bidak Berbeda Bermakna \\
\hline \multirow{2}{*}{ K4 } & K1 & $p<0,001$ & Berbeda Bermakna \\
& K2 & 0,031 & Berbeda Bermakna \\
& K3 & 0,880 & Tidak Berbeda Bermakna \\
\hline
\end{tabular}

Pada penelitian ini yang dilihat yaitu pada pos tes FRAP kelompok 3 dan 4 (Tabel 5), karna ingin membandingkan antara kelompok pembanding (glibenklamid) dan perlakuan (ekstrak etanol daun belimbing wuluh). Pada hasil analisis pos hoc pretest dan post-test hasil FRAP, didapatkan hasil bahwa perbandingan antar kelompok yang memiliki nilai $p>0,05$ adalah kelompok 3 dan kelompok 4, dan kelompok 4 dengan kelompok 3. Hal ini menunjukkan bahwa secara statistik, kapasitas antioksidan darah dengan perlakuan glibenklamid selama 10 hari dapat mengembalikan kapasitas antioksidan darah yang setara dengan kapasitan antioksidan darah tikus normal. Pemberian ekstrak etanol daun belimbing wuluh selama 10 hari secara statistik menunjukan rata-rata besar kapasitas antioksidan darah yang tidak berbeda secara signifikan dengan kelompok yang diberi perlakuan dengan glibenclamid namun berbeda bermakna jika dibandingkan dengan rerata besar kapasitas antioksidan darah tikus kelompok normal.

\section{KESIMPULAN DAN SARAN}

Ekstrak etanol daun belimbing wuluh dengan kandungan antioksidan yang tinggi mempengaruhi penurunan kadar gula darah tikus jantan galur Wistar yang diinduksi streptozotosin. Kapasitas antioksidan darah pada kelompok yang diberi glibenklamid dan kelompok yang diberi ekstrak etanol daun belimbing wuluh tidak berbeda signifikan jika dilihat secara statistik yang dapat dilihat dari angka signifikansinya yaitu 0,880. Estrak etanol daun belimbing wuluh (Averrhoa bilimbi L.) dan glibenklamid mempunyai efek dalam menurunkan kadar gula darah pada tikus yang diinduksi streptozotosin yang dibuktikan 
Tri Wahyuni, Eva Nurinda, Rizal Fauzi

Potensi Antioksidan Ekstrak Etanol Daun Belimbing Wuluh (Averrhoa Bilimbi L.) dan Pengaruhnya Terhadap Kadar Gula Darah Pada Tikus Wistar Jantan yang Diinduksi Streptozotocin (STZ)

dengan adanya perubahan rata-rata besar kadar gula darah tikus pre perlakuan glibenklamid sebesar $258,4117 \mathrm{mg} / \mathrm{dL}$ dan setelah perlakuan sebesar $126,4300 \mathrm{mg} / \mathrm{dL}$ dan perubahan rata-rata kadar gula darah pada pre perlakuan ekstrak etanol daun belimbing wuluh sebesar $257,7717 \mathrm{mg} / \mathrm{dL}$ dan setelah perlakuan sebesar 149,0933 mg/dL.

Hasil penelitian ini dapat dilanjutkan untuk mendapatkan isolasi kandungan metabolit sekunder yang bertanggung jawab terhadap kemampuannya dalam penurunan kadar glikemik. Selain itu dapat modifikasi ekstrak menjadi fraksinasi untuk memperoleh hasil kontrol glikemik yang optimal dapat dilakukan sehingga nantinya akan menjadi sediaan farmasi yang dapat dimanfaatkan masyarakat terutama dengan diabetes melitus sebagai obat herbal pendamping obat kimia dalam mencegah komplikasi DM melalui terkontrolnya glukosa di dalam darah.

\section{KONFLIK KEPENTINGAN}

Seluruh penulis menyatakan tidak terdapat potensi konflik kepentingan dengan penelitian dan atau publikasi artikel ini.

\section{DAFTAR PUSTAKA}

1. Satriany P. pengaruh pemberian ekstrak herba daun sendok (Plantago Major L) terhadap kadar glukosa darah mencit balb/c induksi Streptozotosin. 2010.

2. Ilmiah J, Sina I, Maulana A, Putra P. Uji aktivitas ekstrak etanol daun belimbing wuluh (Averrhoa bilimbbi L.) terhadap penurunan kadar glukosa darah mencit putih jantan yang diinduksi aloksan. 2017;2(September):263-9.

3. Agriani CG. Efek ekstrak batang belimbing wuluh (Averrhoa bilimbi L.) terhadap kadar gula darah tikus putih (Rattus novergicus) yang diinduksi aloksan. 2012.

4. Wulandari A. Penderita Diabetes Mellitus Di Instalasi Rawat Inap Rumah Sakit Umum Daerah Kota Salatiga Tahun 2008. 2009.

5. kementrian kesehatan republik Indonesia. Infodatin pusat data dan informasi kementrian kesehatan RI. 2018.

6. Joddy Sutama Putra R, Achmad A, Rachma Pramestutie H. Kejadian Efek Samping Potensial Terapi Obat Anti Diabetes Pada Pasien Diabetes Melitus Berdasarkan Algoritme Naranjo. Pharm J Indones. 2017;2(2):45-50.

7. Pandanwangi S, Zuniarto ahmad azrul, Mubarok $\mathrm{H}$. Analisa drug related problems (DRPS) pasien gagal ginjal. 2018;3(1).

8. Fatmawati A, Bachri MS, Nurani LH. Combination Effects of Moringa oleifera Leaf Ethanol Extract and Andrographis paniculata Herb on Blood Glucose Levels and Pancreas Histopathology of Diabetic Rats Induced by Streptozotocin. Maj Obat Tradis. 2019;24(2):85.

9. Hasim H, Arifin YY, Andrianto D, Faridah DN. Ekstrak Etanol Daun Belimbing Wuluh (Averrhoa bilimbi) sebagai Antioksidan dan Antiinflamasi. J Apl Teknol Pangan. 2019;8(3):86. 
10. Alassadi IJB, Abd-alla ZS. Isolasi dan Identifikasi Senyawa Flavonoid dari Ekstrak Etanol Buah Belimbing Wuluh (Averrhoa Bilimbi L.) dengan Metode Spektrofotometri Uv-vis. J Farm Galen. 2008;30:357-62.

11. Zaidan S, Djamil R. $\mathrm{n}$-Butanol dari ekstrak metanol daun belimbing wuluh ( Averrhoa bilimbi L.). 2013.

12. Kusumawardani N. Antiinflmasi Macaranga Tanarius [Internet]. Universitas Sanata Dharma. Yogyakarta; 2015. Available from: https://repository.usd.ac.id/2536/.

13. Prabowo, A.Y. Estiasih I. Purwaningrum. Prabowo, A.Y, T. Estiasih, I. Purwatiningrum. 2014. Umbi Gembili (Dioscorea esculenta L.) sebagai Bahan Pangan Mengandung Senyawa Bioaktif. Jurnal Pangan dan Agroindustri. 2(3):129-135. 2014.

14. Nurmawati T. Study of physiological response and white rats (Rattus noorvegicus) blood glucose levels that streptozotocin exposed. J Ners dan Kebidanan (Journal Ners Midwifery). 2017;4(3):244-7.

15. Evi kurniawati eka endah lestari. uji efektivitas daun belimbing wuluh (averrhoa bilimbi L.) sebagai pengobatan diabetes mellitus. 2012;1(1):59-63.

16. Rukmawati, Mita and Hadi, Hamam and Nurinda, Eva and Emelda, Emelda and Fauzi, Rizal and Estiningsih, Daru and Kurniasari, Yulinda and Aprilia V. Comparison of Reduction Fasting Blood Glucose (GDP) by Giving Amorphophallus Onchophyllus and Strobilanthes Crispa on Type 2 Wistar Rat (Rattus Novergicus) Induced by Streptozotosin. In: The First Asia - Pasific Partnership on Health And Nutrition Improvement (Aphni) Conference [Internet]. Yogyakarta: Universitas Alma Ata, Yogyakarta; 2019. Available from: http:// elibrary.almaata.ac.id/1851/.

17. Asmat U, Abad K, Ismail K. Diabetes mellitus and oxidative stress-A concise review. Saudi Pharm J [Internet]. 2016;24(5):547-53. Available from: http://dx.doi.org/ 10.1016/j. jsps.2015.03.013.

18. Deng L, Du C, Song P, Chen T, Rui S, Armstrong DG, et al. Molecular Mechanisms of Dietary Bioactive Compounds in Redox Balance and Metabolic Disorders. Oxid Med Cell Longev. 2021;2021(Figure 1):1-11. 